\title{
Raising Student's Self-Efficacy: The Role of Metacognitive Training
}

\author{
Zahra Bouchkioua \\ Department of Psychology, Faculty of Literature and Human Sciences, Mohammed V University, Rabat, Morocco \\ Email: zahra.bouchkioua@um5.ac.ma
}

How to cite this paper: Bouchkioua, $\mathrm{Z}$. (2021). Raising Student's Self-Efficacy: The Role of Metacognitive Training. Psychology, 12, 1900-1910.

https://doi.org/10.4236/psych.2021.1211115

Received: September 23, 2021

Accepted: November 27, 2021

Published: November 30, 2021

Copyright () 2021 by author(s) and Scientific Research Publishing Inc. This work is licensed under the Creative Commons Attribution International License (CC BY 4.0).

http://creativecommons.org/licenses/by/4.0/

\begin{abstract}
Students need to perform believing in their self-efficacy, which lies in the agency mechanisms. Otherwise, the sense of self-efficacy is necessary to produce results. Students' abilities interact with environments features according to the sociocognitive approach. Metacognition, defined as learner's introspective and conscious knowledge, lies in the sense of self-efficacy perceived in the way that metacognitive believes, in occurrence, corroborate learner's production. In this research, on the one hand, we ask if the Sense of the Perceived Self-Efficacy correlates to the metacognition. On the other hand, we are looking to enhance Perceived Self-Efficacy by training students to raise their metacognitive strategies. The experimental process answers those questions forward a one hundred psychology student's group dispatched in three subgroups to receive practical training and a pre and a post-test for the experimental group, and a passion of pre and post-test without practical training for the first group control, and a second controlling group for the only post-test taking. Results show that effectively students' Perceived Self-Efficacy correlate to their metacognitive strategies $(r=0.05)$. Training on metacognitive strategies (setting goals, controlling one's attention, thinking about the sources of one's difficulties, choosing activities, reflecting on learning strategies, evaluating goals) had substantial effects at the experimental group level $(t=7.10$; significant at, 000).
\end{abstract}

\section{Keywords}

Perceived Self-Efficacy, Metacognition, Motivation, Sociocognitive, Training

\section{Introduction}

Belief in self-efficacy (Bandura, 1986) is one of the most widespread agency mechanisms (Bandura, 1989). Bandura defines this Sense of self-efficacy as Per- 
ceived self-efficacy is about an individual's belief in their ability to organize and execute the course of action required to produce desired results. The student agent is the one who will act on his functioning and his environment. The principle of the agency is based on the postulate of triadic causality (Bandura, 1986, $1989,1997,1999,2001,2006)$. The socio-cognitive approach lies in the social conception of the self, which acts on itself and its environment. To function effectively requires the possession of skills and positive beliefs at the same time. The progressive mastery of skills is necessary for this learning (Hamers \& Csapo, 1999). The Sense of Perceived self-efficacy refers to an individual's beliefs in performing a task successfully (Sadri \& Robertson, 1993). Metacognition (Flavell, 1976) is the learner's introspective and conscious knowledge (Nelson, 1996) about his ways of learning and his ability to regulate his ways. Metacognition assumes different aspects (Rogier et al., 2021), namely: metacognitive functioning, metacognitive believes, and metacognitive awareness.

\section{The Conceptual Framework}

\subsection{The Perceived Self-Efficacy}

The critical contribution of the sociocognitive approach lies in the social conception of the self, which acts on itself and its environment. "Individuals contribute in part to what they do and to what they become." On the one hand, triadic causality helps explain the interaction of socio-cultural factors and personal factors. On the other hand, it assures the freedom of agents to act. The feeling of personal efficiency occupies a central place in the sociocognitive approach as it influences the choice of activities and the development of motivation. It plays an essential role in the structuring of knowledge responsible for future skills. In addition, beliefs about self-efficacy help regulate motivation. Bandura assumes that a belief in high efficiency leads to a high level of production and performance and that doubt about this efficiency can decrease performance (Bandura, 1997). To function effectively requires the possession of skills and positive beliefs at the same time. Beliefs about efficiency have the power to act by modifying them on cognitive processes, motivation levels, the stability of emotional states, and therefore, the achievement of the expected performance at the end of the process. Beliefs about self-efficacy are positive in that they allow one to look directly at mastery experiences, modeling experiences (or vicarious experiences). In addition, self-efficacy beliefs belong to defined contexts that call for specific assessments.

Self-efficacy is not a decontextualized global disposition assessed by a general test, but rather a multifaceted phenomenon. Self-efficacy can be general (Bandura, 1997) and reflects a generalization across various domains of functioning in which people judge how efficacious they are. For most applications, Perceived Self-Efficacy adopts different conceptual patterns in a situation-specific manner. However, it may explain a broader range of human behaviors and coping outcomes when the context is less specific. It might be helpful when focusing on 
multiple behaviors simultaneously (Luszczynska, Gibbons, Piko, \& Tekozel, 2004). Self-efficacy can also carry a specific task in a specific domain. However, some researchers have also conceptualized a generalized sense of self-efficacy that refers to a broad and stable sense of personal competence to deal effectively with various stressful situations (Schwarzer \& Jerusalem, 1995; Sherer et al., 1982).

\subsection{Metacognition}

According to the socio-cognitive approach, direct motivation thought and human action generally depend on several factors that act, interact, and function as regulators of the motivations and the human being's cognitive, social, and behavioral components. According to Bandura (Bandura, 1980), the individual responds to a stimulus after interpreting it. Reinforcement takes place after awareness. Furthermore, the three factors united by the causal and triadic relationship do not intervene with the same intensity, nor are they present in all situations. The individual acts and suffers the effects of the environment; this is what the principle of bidirectionality sums up. We assume (Bouchkioua, 2012) that training students in learning strategies and, in particular, those correlated to the Perceived Self-Efficacy enhance the Perceived Self-Efficacy. The use of metacognitive strategies (Azevedo, 2020) involves, in difficult situations, the following attitudes:

- identify the feasibility of the task

- persist in the face of obstacles

- set high goals

- identify available resources and know-how to use them

- accept and use the error in the learning process

Metacognition corresponds to the awareness that students' learning is a cornerstone of their success (Romainville, 2007) in how an individual's state of awareness of one's cognitive processes (Richard \& Gighlione, 1993) is triggered (Nelson, 1996; Nguyen-Xuan, 1990). We opt for the pedagogical perspective of metacognition (Romainville, 2007): the student exercises his metacognition, either when he reports explicit knowledge of his cognitive functioning or when he intentionally controls and adapts the latter to achieve a learning objective. This way of posing metacognition clearly emphasizes the importance of consciousness in this process. The pedagogical perspective has a base on Flavell's metacognitive conception (Flavell, 1987).

1) A declarative aspect: Knowledge is related to the learner's learning style, the task incumbent upon him, or learning strategies.

2) A procedural aspect: The learner is probably metacognitive since he acts through his conscious thought on his cognitive action (Pinard, 1989). Beyond success, Romainville (Romainville, 2000), aptly evoking the Piagetian dichotomy (Piaget, 1974) (succeeding versus understanding), recognizes metacognition as its role in learning. The transfer is also dependent on metacognitive capacities insofar as these make it possible to become aware of adequate or deficient learn- 
ing capacities to transfer them into new learning situations (Kail \& Fayol, 2000). Adequate methodological support based on the learner's initial conceptions. After a methodological support action, the methodical student is the one who reflects on his acquired methodological skills and others to acquire. This conscious reflection thus allows him to develop his metacognition and his methodological capacities. Methodological support (Romainville, 2007) by conscious (Houart \& Vastersvandt, 1996) training (Earley, 1994) has its added value to enrich the range of student strategies vis-à-vis their methodological prerequisites and the particularities of the learning context. The methodological support is an opportunity to carry out conceptual work via the metacognitive approach (Zepada et al., 2018). Reflect on their methods, on the sources of their difficulties, choose or not the activities incumbent on them, control their attention, set goals, reflect on their learning, cognitive and managerial strategies; these are the indicators that make it possible to check the metacognitive strategies (MS) of the student.

By methodological support, specialists often refer to activities (see appendix: Training program (extract)) designed by teachers as part of their courses or a course created for this purpose to help students progress in their studies, their ways of learning, and their methods of learning. in general (Frenay et al, 1998; Wouters et Deketele, 1993). Methodological support starting from specific content acts on cognitive skills (understanding, analysis, memorization, and structuring). After methodological training, the development of these skills makes it possible to obtain other skills such as metacognitive skills.

\section{The research Methodology}

This research aims to look for a link between the Sense of Perceived Self-Efficacy and metacognition and, secondly, an subsequent effect of the metacognitive's strategies (see Table 1). The experimental process seems to suit to answer those questions forward a one hundred psychology student's group $(\mathrm{N}=100)$ dispatched in three subgroups to receive practical training and a pre and a post-test $(\mathrm{N}=35)$ for the experimental group, and a passion of pre and post-test without practical training for the first group control $(\mathrm{N}=40)$, and a second controlling group for the only post-test taking. We choose to build an appropriate measuring tool most adequate to Moroccan students and context. Moreover, we agree with Thomas, Anderson, and Nashon (Thomas et al., 2008) if they assume that metacognition has a measured in practical context whiting an instructing experience and not only theoretically as the MSLQ (Pintrich \& Garcia, 1993; Pintrich et al., 1991), the LASSI (Weinstein et al., 1987), the ACME (Osborne, 1998) and the LPQ (Biggs, 1987).

\section{The Main Results}

To answer the question about a link between self-efficacy and metacognitive strategies, we recur to the correlation analysis at the pre-test (see Table 2) and post-test (see Table 3 ). 
Table 1. (a) Metacognitive strategies (MS) and correspondence items; (b) SPSE and correspondents' items.

(a)

Overall, I read general culture books

a-Setting goals

2. At the start of each module, I set myself goals

3. At the start of each module, I wait for the teacher to set goals

4. I wait for the end of the module to pass the control

5. During the lessons, I understand the basics
6. During class, I can write the essentials
7. When the teacher is doing the lesson, I try to write everything down
8. When the teacher is giving the lesson, I try to write down what I think is relevant
9. While working on my lessons, I always think about what I am doing
10. While working on my lessons, I often think about what I am doing
11. While working on my lessons, I rarely think about what I am doing
12. While working on my lessons, I never think about what I am doing
13. During the course, I pay attention to some parts of the course
14. My attention during a class depends on the atmosphere in which I find myself
15. My attention during a class depends on the teacher's way of doing
16. My attention during a class depends on the ideas I think about
17. In class, my attention is due to
$\square$ The teacher's way of doing the lesson
$\square$ I enjoy this module
$\square$ It is an exciting module for my professional future
18. During the lesson, I pay attention to the teacher's instructions:

MS

19. I think about solutions to the difficulties of revisions

c-Reflect on the sources

20. I think about solutions to exam difficulties

of one's difficulties

21. I can detect the origins of my difficulties during class

22. I can detect the origins of my difficulties during revisions

23. I manage to detect the origins of my difficulties during checks

\section{d-Choice of activities 24. I choose the activities I should do}

25. When I read a course text or a reference book, I use a language and specialty dictionary

26. When I read a course text, I find the logical links of text

27. I observe the plan to identify the essentials in a text 28 . When I read, I identify the keywords

29. I summarize the main idea of the document I read

30. I read the introduction and the conclusion first

e-Reflect on learning strategies

31. I copy whole pieces of text

32. To improve my language level, I listen to programs in French

33. I read texts in French

34. Once at home in the evening, I bind my notes, and I rearrange them according to the above

35. My revisions consist of

$\square$ Memorize the whole course

$\square$ Remember the course summary

$\square$ Withhold parts of lessons

f-Evaluate the achievement of objectives
36. After each check-up, I compare my results to those of my group mates

37. After each check-up, I compare my results with the goals I have already set

38. After each check-up, I compare my current results to those I have already achieved 
(b)

\begin{tabular}{ccccccc}
\hline \multirow{3}{*}{ Components } & \multicolumn{3}{c}{ initial eigenvalue } & \multicolumn{2}{c}{ extraction of sums of squares of the selected factors } \\
\cline { 2 - 6 } & Total & \% of variance & cumulative\% & Total & \% of variance & cumulative\% \\
\hline 1 & 1.993 & 15.332 & 15.332 & 1.993 & 15.332 & 15.332 \\
2 & 1.674 & 12.874 & 28.206 & 1.674 & 12.874 & 28.206 \\
3 & 1.457 & 11.208 & 39.414 & 1.457 & 11.208 & 39.414 \\
4 & 1.321 & 10.161 & 49.576 & 1.321 & 10.161 & 49.576 \\
5 & 1.145 & 8.810 & 58.386 & 1.145 & 8.810 & 58.386 \\
\hline
\end{tabular}

\begin{tabular}{|c|c|c|c|c|c|c|}
\hline \multicolumn{7}{|c|}{ Component matrix } \\
\hline & \multicolumn{6}{|c|}{ Components } \\
\hline & 1 & 2 & 3 & 4 & 5 & 6 \\
\hline $\begin{array}{l}\text { Q39: During the course, I do not note anything because } \\
\text { I have the handout }\end{array}$ & .129 & .213 & -.067 & -.583 & -.398 & .104 \\
\hline Q40: Overall, I owe my feelings of pride to my efforts & .482 & .268 & -.112 & -.167 & .391 & -.440 \\
\hline $\begin{array}{l}\text { Q41: Overall, I owe my feelings of pride to the image I } \\
\text { have with my comrades }\end{array}$ & -.125 & .746 & -.139 & .159 & .034 & -.176 \\
\hline Q42: Overall, in terms of studies, I judge myself & .269 & -.449 & .531 & -.170 & .219 & .227 \\
\hline
\end{tabular}

Extraction method: Principal component analysis a. six extracted components.

Table 2. The correlation coefficient between the SPSE and the MS at the pre-test.

\begin{tabular}{|c|c|c|c|}
\hline \multicolumn{4}{|c|}{ Correlations } \\
\hline & & SPSE & MS \\
\hline \multirow{3}{*}{ SPSE } & Pearson Correlation & 1.000 & .062 \\
\hline & Sig. (unilateral) & . & .334 \\
\hline & $\mathrm{N}$ & 71 & 51 \\
\hline \multirow{3}{*}{ MS } & Pearson Correlation & .062 & 1.000 \\
\hline & Sig. (unilateral) & .334 & . \\
\hline & $\mathrm{N}$ & 51 & 52 \\
\hline
\end{tabular}

Table 3. The correlation coefficient between the SPSE and the MS at the post-test.

\begin{tabular}{ccc}
\hline \multicolumn{3}{c}{ Correlations } \\
\hline & SPSE (post-test) & $\begin{array}{c}\text { Metacognitive strategies } \\
\text { (post-test) }\end{array}$ \\
\hline SPSE on Pearson correlation & 1.000 & $.213^{\star}$ \\
Sig. (unilateral) & .019 \\
(post-test) N & 113 & 95 \\
\hline $\begin{array}{c}\text { Metacognitive strategies Pearson correlation } \\
\text { (post-test) Sig. (unilateral) }\end{array}$ & $.213^{\star}$ & 1.000 \\
$\mathrm{~N}$ & .019 &. \\
\hline
\end{tabular}

${ }^{\star}$ The correlation is significant at the 0.05 level (unilateral). 
We can thus conclude that the linear relationship between the SPSE and the MS has statistical significance in the post-test.

Next, we present the results relating to the conscious training program (see Table 4) of MS and their possible effect on SPSE in the experimental group.

1) The mean post-test score of the experimental group (72.68) is higher than that of the pre-test (56.71). This change is significant $(t=7.10$; significant at, 000). We can deduce the effect of training in MS.

The mean post-test score of the experimental group (72.68) is higher than that of the control group 1 (post-test: 64.46). This difference is significant $(t=7.12$; significant at, 000).

2) The mean post-test score (64.46) is higher than the pre-test of control group 1 (54.83). This change is significant $(t=14.79$; significant at, 000). We deduce from this a modification of metacognitive strategies in the students of the control group 1.

3) The mean score at the experimental group's post-test (72.68) is different from the mean score (post-test: 62.91) of the control group 2. This difference is significant $(t=7.25 ; 000)$.

\section{Discussion}

Training on metacognitive strategies (setting goals, controlling one's attention, thinking about the sources of one's difficulties, choosing activities, reflecting on learning strategies, evaluating goals) had substantial effects at the experimental group level. Metacognitive strategies also experienced a change at the control group level1.

Reflect on the sources of one's difficulties (choose activities, reflect on their learning strategies, evaluating the achievement of objectives) on the historical past, as well as the possibilities of adaptation to the university rhythm, had the expected effects on the metacognitive strategies and the motivation of the student.

Following the results obtained, we believe that self-efficacy and the self-regulatory metacognitive strategies were able to take advantage of the chosen theoretical and methodological framework. The sociocognitive approach and methodological support are directed simultaneously towards learning autonomy, the semantic contribution of reciprocal self-determinism, and the importance of

Table 4. The t-student on training in MS.

\begin{tabular}{lcccc}
\hline & $\begin{array}{c}\text { Average score } \\
\text { (pre-test) }\end{array}$ & $\begin{array}{c}\text { Average score } \\
\text { (post-test) }\end{array}$ & $\mathrm{t}$ & Sig \\
\hline Experimental group & 56.71 & 72.68 & 7.10 & .000 \\
Control group 1 & 54.83 & 64.46 & 7.12 & .000 \\
$\begin{array}{l}\text { Control group 1 pre-test } \\
\text { versus post-test }\end{array}$ & 54.83 & 64.46 & 14.79 & .000 \\
Control group 2 & - & 62.91 & 7.25 & 000 \\
\hline
\end{tabular}


context in the analysis and understanding of motivation. These results mean improving self-efficacy, an essential component of human motivation, methodological, metacognitive, managerial, and self-regulating training, as well as all the methods of the students of group experimental. The means of the pre-test and post-test of the experimental group generally changed. We conclude that:

- It is possible to act and reduce learning difficulties in students by changing their motivation.

- Methodological support and psycho-pedagogical support improve Self-efficacy and the learning strategies it conveys.

Finally, we quote Rogers (Rogers, 1969), who stipulates that education is a total operation addressed to the whole personality and not a transmission of knowledge, and Bandura (1986), who believes that motivation is what one believes in doing.

\section{Conflicts of Interest}

The author declares no conflicts of interest regarding the publication of this paper.

\section{References}

Azevedo, R. (2020). Reflections on the Field of Metacognition: Issues, Challenges, and Opportunities. Metacognition Learning, 15, 91-98. https://doi.org/10.1007/s11409-020-09231-x

Bandura, A. (1980). Gauging the Relationship between Self-Efficacy Judgment and Action. Cognitive Therapy and Research, 4, 263-268. https://doi.org/10.1007/BF01173659

Bandura, A. (1986). Social Foundations of Thought and Action: A Social Cognitive Theory. Prentice-Hall, Inc.

Bandura, A. (1989). Human Agency in Social Cognitive Theory. American Psychologist, 44, 1175-1184. https://doi.org/10.1037/0003-066X.44.9.1175

Bandura, A. (1997). Self-Efficacy: The Exercise of Control. WH Freeman/Times Books/Henry Holt \& Co.

Bandura, A. (1999). A Social Cognitive Theory of Personality. In L. Pervin, \& O. John (Eds.), Handbook of Personality (pp. 154-196). Guilford Publications.

Bandura, A. (2001). Social Cognitive Theory: An Agentic Perspective. Annual Review of Psychology, 52, 1-26. https://doi.org/10.1146/annurev.psych.52.1.1

Bandura, A. (2006). Toward a Psychology of Human Agency. Perspectives on Psychological Science, 1, 164-180. https://doi.org/10.1111/j.1745-6916.2006.00011.x

Biggs, J. (1987). Learning Processes Questionnaire. Australian Council for Educational Research.

Bouchkioua, Z. (2012). La motivation et les stratégies d'apprentissage de l'étudiant universitaire. Doctoral Thesis, Mohammed V Souissi University, Faculty of Education Sciences.

Earley, P. C. (1994). Self or Group? Cultural Effects of Training on Self-Efficacy and Performance. Administrative Science Quarterly, 39, 89-117. https://doi.org/10.2307/2393495

Flavell, J. H. (1976). Metacognitive Aspects of Problem-Solving. In L. B. Resnick (Ed.), 
The Nature of Intelligence (pp. 231-235). Lawrence Erlbaum.

Flavell, J. H. (1987). Speculation about the Nature and Development of Metacognition. In F. E. Weinert, \& R. H. Kluwe (Eds.), Metacognition Motivation and Understanding (pp. 21-29). LEA.

Frenay, M., Noel, N., Parmentier, Ph., \& Romainville, M. (1998). L'étudiant-apprenant. Grille de lecture pour l'enseignement universitaire. Deboeck Université.

Hamers, J., Van Luit, J., \& Csapo, B. (1999). Teaching and Learning Thinking Skills. Lisse, Sweets \& Zeitllinger Publishers.

Houart, M., \& Vastersavendts, G. P. (1996). De l’apprentissage de méthodes ... à la motivation. Cahiers pédagogiques.

Kail, M., \& Fayol, M. (2000). L'acquisition du langage. Vol. II. Le language en développement. Au delà de trois ans. Presses Universitaires de France.

https://doi.org/10.3917/puf.fayol.2000.02

Luszczynska, A., Gibbons, F. X., Piko, B. F., \& Tekozel, M. (2004). Self-Regulatory Cognitions, Social Comparison, and Perceived Peers' Behaviors as Predictors of Nutrition and Physical Activity: A Comparison among Adolescents in Hungary, Poland, Turkey, and the USA. Psychology and Health, 19, 577-593.

https://doi.org/10.1080/0887044042000205844

Nelson, T. (1996). Consciousness and Metacognition. American Psychologist, 51, 102-116.

Nguyen-Xuan, A. (1990). Conscience, prise de conscience et métacognition. dans J.-F.

Osborne, J. W. (1998). Measuring Metacognition: Validation and Assessment of Cognition Monitoring Effectiveness. Unpublished Ph.D. Thesis, State University of New York.

Piaget, J. (1974). Réussir et comprendre. Presses Universitaires de France.

Pinard, A. (1989). La conscience psychologique. Presses de l'Université du Québec.

Pintrich, P. R., \& Garcia, T. (1993). Student Goal Orientation and Self-Regulation in the College Classroom. Advances in Motivation and Achievement, 7, 371-402.

Pintrich, P. R., Smith, D., Garcia, T., \& McKeachie, W. J. (1991). A Manual for the Use of the Motivated Strategies for Learning Questionnaire (MSLQ). ERIC Document Reproduction Service No. ED 338 122, National Center for Research to Improve Post-Secondary Teaching and Learning.

Richard, C. B., \& Ghiglione, R. (1993). Traité de psychologie cognitive; le traitement de l'information symbolique (pp. 210-217). Dunod.

Rogers, K.-R. (1969). Freedom to Learn. Charles E. Merril Publishing Company.

Rogier, G., Beomonte Zobel, S., Morganti, W., Ponzoni, S., \& Velotti, P. (2021). Metacognition in Gambling Disorder: A Systematic Review and Meta-Analysis. Addictive Behavior, 112, Article ID: 106600.

https://doi.org/10.1016/j.addbeh.2020.106600

Romainville, M. (2000). Savoir comment apprendre suffit-il àmieux apprendre? métacognition et amélioration des performances. In S. la, D. de, R. Pallascio, \& L. Lafortune (eds.), Pour une pensée réflexive en éducation (pp. 71-85). Presses de l'universitédu Québec. https://doi.org/10.2307/j.ctv18pgm0v.7

Romainville, M. (2007). Conscience, métacognition, apprentissage: Le cas des compétences méthodologiques. In D. F. Pons, \& P. A. Doudin (Eds.), La conscience: Perspectives pédagogiques et psychologiques. Presses de l'université du Québec.

Sadri, G., \& Robertson, I. T. (1993). Self-Efficacy and Work-Related Behaviour: A Review and Meta-Analysis. Applied Psychology, 42, 139-152.

https://doi.org/10.1111/j.1464-0597.1993.tb00728.x 
Schwarzer, R., \& Jerusalem, M. (1995). Generalized Self-Efficacy Scale. In J. Weinman, S. Wright, \& M. Johnston (Eds.), Measures in Health Psychology: A User's Portfolio. Causal and Control Beliefs (pp. 35-37). NFER-NELSON.

Sherer, M., Maddux, J. E., Mercandante, B., Prentice-Dunn, S., \& Jacobs, B. (1982). The Self-Efficacy Scale: Construction and Validation. Psychological Reports, 51, 663-671. https://doi.org/10.2466/pr0.1982.51.2.663

Thomas, G., Anderson, D., \& Nashon, S. (2008). Development of an Instrument Designed to Investigate Elements of Science Students' Metacognition, Self-Efficacy, and Learning Processes: The SEMLI-S. International Journal of Science Education, 30, 1701-1724. https://doi.org/10.1080/09500690701482493

Weinstein, C. E., Schulte, A. C., \& Palmer, D. P. (1987). Learning and Study Strategies Inventory. $\mathrm{H} \& \mathrm{H}$ Publishing.

Wouters, P., \& Deketele, J. M. (1993). Les dispositifs de préparation des étudiants a l'enseignement superieur et universitaire. RES Academia, 11, 41-72.

Zepada, C. D., Hlutkowsky, C. O., Partika, A. C., \& Nokes-Malach, T. J. (2018). Identifying Teachers' Supports of Metacognition through Classroom Talk and Its Relation to Growth in Conceptual Learning. Journal of Educational Psychology, 111, 522-541. https://doi.org/10.1037/edu0000300 


\section{Appendix: Training Program (Extract)}

Exercise 1: The poly copy

Objective: Encourage students to apply their knowledge of note-taking (NT) on one of their handouts

Modality: Group work

Support: The handout (document $\mathrm{n}^{\circ} 3$ )

Presentation time: $15 \mathrm{mn}$

Instructions:

- Read your handout individually

- Get into a group of four to discuss it for an hour (in class)

- Agree on the most critical points

- Take notes individually

- Present in next class

- What are the difficulties you encountered?

Exercise 2: The chapter

Objective: Apply knowledge about NT

Modality: Individual work

Support: Scheduled book chapter (document $\left.n^{\circ} 4\right)+$ written document to be returned

Instructions:

- Read the chapter (document $n^{\circ} 4$ )

- Make it the NT

- Mark your observations

- Consult the subject teacher to check the correctness of your notes

- Submit your work to the next methodology course

Exercise 3: Updating knowledge

\section{A) Revision}

Part of the review and preparation for the exams has already started through the readings, NT, reading cards, concept maps, and summaries. The last stage of the review makes more synthesis strategies for the student, his time, and stress management skills.

Thus, in this chapter, we offer stress management activities and time management activities.

B) Stress management

Exercise $\mathrm{n}^{\circ}$ 1: Theoretical presentation

Objective: Inform about stress

Modality: Group work

Support: Computer + data show

Duration: 20 to $30 \mathrm{~min}$

Instructions:

- Prepare a brief presentation on stress at university

- Compare this information with your own experience

- Draw conclusions 